\title{
Necrotising enterocolitis and nutrition
}

\begin{abstract}
The incidence of Necrotising enterocolitis (NEC) varies widely but occurs in approximately 1 in 1000 live births and up to $10 \%$ of Extremely Low Birth Weight Infants. Mortality is high around $20-30 \%$ but highest in preterm infants and in those requiring surgery. There is an association with feeds and bacteria in the pathogenesis as well as bacterial toxins. Formula milk is associated with a higher incidence of NEC than those infants receiving human milk or a mixture of both. There is no benefit in delaying the introduction of enteral feeds with breast milk but the rate of increase remains an area for research and discussion. An adopted standardized regime does appear to be protective. Further improvements in the prevention, diagnosis and treatment of NEC are still required.
\end{abstract}

Volume 2 Issue 4 - 2017

Julian David Eason

Department of Neonatology, Corniche Hospital, UAE

Correspondence: Julian David Eason, Department of Neonatology, Corniche Hospital, UAE, Tel 7|26724900, Fax 97126726348, Email julianE@cornichehospital.ae

Received: December 14, 2014 | Published: July 27, 2015

Keywords: necrotising enerocolitis, prebiotics, probiotics, breast milk

\section{Case report}

The incidence of Necrotising enterocolitis (NEC) varies widely but occurs in approximately 1 in 1000 live births and up to $10 \%$ of Extremely Low Birth Weight Infants. ${ }^{1}$ Mortality is high around 20 $30 \%$ but highest in preterm infants and in those requiring surgery. The common site for NEC to occur is the terminal ileum, caecum and ascending colon but it can occur anywhere in gastrointestinal tract. The process is essentially inflammatory becoming transmural associated with ulceration, necrosis, oedema, haemorrhage and potential perforation. There is an association with feeds and bacteria

Table I Bells staging

\begin{tabular}{|c|c|c|c|}
\hline Stage & Systemic Signs & Intestinal Signs & Radiology \\
\hline IA Suspected & Apnoea, Bradycardia, Temp instability & Gastric residuals, mild distention, occult blood & Normal or ileus \\
\hline IB Suspected & As Above & As Above plus fresh blood per rectum & Normal or ileus \\
\hline I I A NEC Mild & As Above & $\begin{array}{l}\text { Above plus absent / decreased bowel sounds, } \\
+/ \text { - tender }\end{array}$ & Dliatation, ileus, pneumatosis \\
\hline $\begin{array}{l}\text { I I B NEC } \\
\text { Moderate }\end{array}$ & $\begin{array}{l}\text { As above mild metabolic acidosis and } \\
\text { thrombocytpoenia }\end{array}$ & $\begin{array}{l}\text { Above plus abdominal tenderness, absent bowel } \\
\text { sounds, }+/ \text { - cellulitis }\end{array}$ & $\begin{array}{l}\text { As IIA }+/ \text { - portal vein gas, } \\
+/ \text { - ascites }\end{array}$ \\
\hline $\begin{array}{l}\text { I I I A NEC } \\
\text { Advanced }\end{array}$ & $\begin{array}{l}\text { As IIB plus hypotension, sever apnoea, mixed } \\
\text { acidosis, DIC, anuria, neutropoenia }\end{array}$ & $\begin{array}{l}\text { Above plus signs of peritonitis, abdominal } \\
\text { distention and abdominal wall erythema }\end{array}$ & As IIA with Ascites \\
\hline $\begin{array}{l}\text { I I IA NEC } \\
\text { Perforation }\end{array}$ & As $\| I \mathrm{~A}$ & As $\| \mathrm{I}$ & $\begin{array}{l}\text { II IA with Ascited plus } \\
\text { pneumoperitoneum }\end{array}$ \\
\hline
\end{tabular}

\section{Milk and its constituents}

Formula milk is associated with a higher incidence of NEC than those infants receiving human milk or a mixture of both. ${ }^{2}$ There is no benefit in delaying the introduction of enteral feeds with breast milk but the rate of increase remains an area for research and discussion. ${ }^{3}$ An adopted standardized regime does appear to be protective. Recommendations include starting feeds at any gestation within the first $1-2$ days of life and advancing around $30 \mathrm{mls} / \mathrm{kg} /$ day in infants $<1000 \mathrm{~g}$. ${ }^{4}$

Prebiotics and Probiotics are advocated as being protective against NEC. Prebiotics are oligosaccharides promoting the growth of the normal bacteria found in the colon but despite this, there is little evidence that they prevent or protect against NEC. Probiotics however can help colonise the gut with normal gut bacteria normalizing the microbiome. Despite meta-analyses demonstrating a reduction in NEC there remain divisions over which strain or strains of bacteria to use or whether we should await further studies before universally recommending the routine use of prob. Many authors do, however, recommend their routine use and offer guides as to how to introduce them into practice. ${ }^{5}$ in the pathogenesis as well as bacterial toxins but no single consistent organism has been implicated.

\section{Clinical presentation}

Presentation varies from feed intolerance, increased aspirates, apnoea and bradycardia to abdominal distention, rectal bleeding and shock. X-ray findings can include fixed loops, pneumatosis intestinalis, portal gas and of course, perforation. Infants progressing to shock often need inotropic and ventilator support. There have been a number of classifications for NEC but 'Bell's staging' is commonly used to classify this disease Table 1 . illness seems plausible. Although some artificial milks and intravenous feeds have been modified to achieve a higher supplementation, long-chain polyunsaturated fatty acids (LCPUFA's), Glutamine and Arginine have failed to show any significant benefits with respect to NEC prevention.

\section{Treatment}

Traditional treatment includes resting the bowel, antibiotics specific to each individual unit's policy, intensive care support and surgery when required. Fluid restriction is often undertaken but calorie content should not be reduced aiming for over $100 \mathrm{kcal} / \mathrm{kg} /$ day. Parenteral intake includes protein, carbohydrate and lipid itself comprising $30-40 \%$ of non-protein calories to allow healing and repair.

The length of time to rest the bowel remains controversial but ordinarily 7-14 days is usual with a guiding reduction in $\mathrm{C}$ reactive protein often seen in the biochemistry albeit not a very sensitive marker. The timing of surgery also remains uncertain and also whether to drain or undergo laparotomy. If perforation has occurred or necrotic 
bowel removed both requiring ileostomy formation then re-feeding may be even slower post-operatively as the inflammation subsides. Human milk is the ideal choice for re-feeing containing growth and immune factors not present in formula.

\section{Strategies to reduce NEC}

Preventing NEC is likely to be a better strategy than improving the treatment modalities. Clearly reducing the number of preterm infants, standardizing feeding guidelines and using breast milk exclusively has impacted on the incidence of NEC. ${ }^{6}$ The components of Breast Milk include, Oligosaccharides, Probiotics, Lactoferrin, AlphaLactalbumin, Lysozyme, Fatty Acids and other factors. This has led to many studies suggesting the regular use of probiotics to help reduce NEC although each study differs greatly and uses many different bacterial species. ${ }^{7,8}$

\section{Conclusion}

Further improvements in the prevention, diagnosis and treatment of NEC are still required and hopefully will aid the reduction of this potentially catastrophic condition for the newborn infant at risk.

\section{Acknowledgments}

None.

\section{Conflicts of interest}

The author declares that there is no conflict of interest.

\section{Funding}

None.

\section{References}

1. Berman L, Moss RL. Necrotising enterocolitis: an update. Semin Fetal Neonatal Med. 2011;16(3):145-150.

2. Sullivan S, Schanler RJ, Kim JH, et al. An exclusively human milkbased diet is associated with a lower rate of necrotizing enterocolitis than a diet of human milk and bovine milkbased products. $J$ Pediatr. 2010;156(4):562-567.

3. Morgan J, Young L, McGuire W. Slow advancement of enteral feed volumes to prevent necrotizing enterocolitis in very low birth weight infants. Cochrane Database Syst Rev. 2014;12:CD001241.

4. Fallon EM, Nehra D, Potemkin AK, et al. ASPEN. Clinical guidelines: nutritional support of neonatal patients at risk for necrotizing enterocolitis. J Parent Nutr. 2012;36(5):506-523.

5. Deshpande G, Rao SC, Keil AD, et al. Evidence based guidelines for use of probiotics in preterm neonates. BMC Medicine. 2011;9:92.

6. Pietz J, Babu A Lawrence L, Erin CS, et al. Prevention of necrotizing enterocolitis in preterm infants: a 20 year experience. Pediatrics. 2007;119(1):164-170.

7. Srinivasjois R, Rao S, Patole S. Prebiotic supplementation in preterm neonates: updated systematic review and meta-analysis of randomized controlled trials. Clin Nutr. 2013;32(6):958-965.

8. Yang Y, Guo Y, Kan Q, et al. A meta-analysis of probiotics for preventing necrotizing enterocolitis in preterm neonates. Braz J Med Biol Res. 2014;47(9):804-810. 